\title{
PERANAN INTERNAL AUDIT TERHADAP PERENCANAAN DAN PENGENDALIAN PIUTANG PADA PT. HADJI KALLA CABANG PALOPO
}

\author{
LISKA, SUHARDI M. ANWAR, SALJU
}

\begin{abstract}
ABSTRAK
Internal audit merupakan orang atau badan yang melaksanakan aktivitas internal audit. Internal audit, diharapkan akan membantu anggota menajemen dalam berbagai hal, seperti menelah prosedur operasi dari berbagai unit dan melaporkan hal-hal yang menyangkut tingkat kepatuhan terhadap kebijaksanaan pimpinan perusahaan, efisiensi, unit usaha atau efektifitas sistem pengawasan intern. Tujuanya adalah mengetahui peranan internal audit terhadap perencanaan dan penegendalian piutang pada PT. Hadji Kalla Cabang Palopo.

Metode yang digunakan adalah Metode Penelitian Lapangan dan Studi Kepustakaan dan termasuk juga di dalamnya data primer dan data sekunder. Data primer dapat dilakukan dengan cara observasi dan wawancara.

Berdasarkan data dari hasil perhitungan diperolah nilai rasio sebesar 1,62 untuk tahun 2010 dan 1,76 untuk tahun 2011. Rasio ini bisa diartikan bahwa jumlah piutang yang dimilikipada tahun 2010, dalam satu tahun perusahaan mampu menkonversi piutang menjadi kas sebanyak 1,62 kali, sedangkan pada tahun 2011 sebanyak 1,76 kali.

Kesimpulan dari hasil perhitungan diperoleh nilai rasio sebesar 1,62 untuk tahun 2010 dan 1,76 untu tahun 2011, rasio ini diartikan bahwa jumlah piutang yang dimiliki pada tahun 2010 dalam satu tahun perusahaan mampu menkonversi piutang menjadi kas sebanyak 1,62 kali, sedangkan pada tahun 2011 sebanyak 1,76 kali. Sedangkan dari hasil perhitungan rata-rata penerimaan piutang untuk tahun 2010 adalah 225 hari, sedangkan untuk tahun 2011 adalah 207 hari. Hal ini menunjukkan bahwa peranan internal audit terhadap perencanaan dan pengendalian piutang pada PT. Hadji Kalla Cabang palopo telah dilaksanakan dengan efektif.
\end{abstract}

Kata Kunci : peran internal audit, perencanaan, pengendalian piutang 


\section{Pendahuluan}

\section{Latar Belakang}

Setiap perusahaan yang didirikan tentu bertujuan untuk memperoleh laba atau keuntungan yang sebesar-besarnya. Penjualan yang dilakukan dapat berupa penjualan tunai maupun dengan penjualan kredit. Banyak perusahaan memberikan kemudahan dalam penjualan produk-produk yang dipasarkan.

Dengan meningkatnya volume penjualan maka diharapkan dapat meningkatkan laba perusahaan. Meningkatkan volume penjualan secara kredit akan menyebabkan investasi dalam piutang meningkat. Pos piutang timbul karena terjadinya suatu transaksi penjualan secara kredit, karena itu pembayaran dan pelunasan sangat erat sekali dengan jangka waktu tertentu.

Peranan Internal Audit dalam mengoptimalkan pengendalian intern piutang yaitu dengan adanya prosedur tetap (protap) yang telah ditetapkan oleh perusahaan sehingga dengan adanya prosedur tetap (protap) yang diterapkan oleh perusahaan diharapkan dapat melakukan peningkatan dalam pengendalian intern piutang serta pengumpulan piutang itu sendiri secara optimal.

Oleh karena itu, masalah tersebut ,maka peranan internal audit terhadap perencanaan dan pengendalian piutang sangat penting dalam mendukung efesiensi dan efektifitas laju perkembangan perusahaan. Bertolak dari hal tersebut maka peneliti mencoba untuk menyusun suatu penelitian dengan judul "Peranan Internal Audit Terhadap Perencanaan dan Pengendalian Piutang Pada PT. Hadji Kalla Cabang Palopo". Masalah penelitian ini adalah apakah dengan internal audit berpengaruh terhadap perencanaan dan pengendalian piutang pada PT. Hadji Kalla Cabang Palopo?. Tujuan penelitian ini adalah untuk mengetahui peranan internal audit terhadap perencanaan dan pengendalian piutang pada PT. Hadji Kalla Cabang Palopo.

\section{Metode Penelitian}

Tempat Dan Waktu Penelitian

Penelitian ini dilakukan pada kantor PT. Hadji Kalla Cabang Palopo yang beralamat di jalan Andi Djemma No. 136 Kota Palopo selama 2 bulan.

\section{Jenis Dan Sumber Data}

- Data Primer, yaitu data yang dikumpulkan dan berhubungan langsung dengan penelitian yang sedang berlangsung.

- Data Sekunder, yaitu data yang diperoleh dari literatur yang ditulis oleh para pakar dibidangnya yang ada kaitannya dengan masalah yang diteliti. 
Metode Pengumpulan Data

Metode pengumpulan data yang digunakan dalam penelitian ini adalah: (a) Penelitian lapangan yaitu penelitian yang dilakukan secar langsung pada PT. Hadji Kalla Cabang Palopo yang menjadi objek penelitian untuk memperoleh objek Data primer ini dapat diperbolehkan melalui: Observasi dan Wawancara, (b) Studi Kepustakaan merupakan metode pengumpulan data yang dilakukan dengan membaca buku-buku, literatur, jurnal-jurnal, referensi yang berkaitan dengan penelitian ini dan penelitian terdahulu yang berkaitan dengan penelitian yang sedang dilakukan.

Metode Analisis Data

Model analisa yang digunakan pada penelitian ini adalah analisis deskriptif kualitatif. Model analisis deskriktif kualitatif ditujukan untuk mendapatkan informasi tentang berbagai kondisi lapangan yang bersifat tanggapan dan pandangan terhadap peran Internal audit terhadap perencanaan dan pengendalian piutang.

Analisis deskriktif-kualitatif merupakan suatu teknik yang menggambarkan dan menginterprestasikan arti dari data-data yang telah terkumpul dengan memberikan perhatian dan merekam sebanyak mungkin aspek situasi yang diteliti pada saat itu, sehingga memperoleh gambaran secara umum dan menyeluruh tentang keadaan yang sebenarnya.

Adapun rasio yang digunakan untuk menghitung perputaran piutang dan lama penagihan piutang menurut Darsono dan Anshari (2005:81) dalam Olla Auryna (2009:69) digunakan rumus sebagai berikut:
Perputaran Piutang
$=\frac{\text { Total Penjualan Kredit }}{\text { Rata-Rata Piutang }}$
Rata-Rata Pertimbangan Piutang
$=\frac{365 \text { hari }}{\text { Puratan Piutang }}$

\section{Hasil Penelitian Dan Pembahasan}

\section{Hasil Penelitian}

PT. Hadji Kalla didirikan oleh Hadji Kalla dan istri, Hj. Athirah Kalla. Pada tanggal 18 Oktober 1952. Memulai usahanya pada bidang perdagangan tekstil dikota Watampone (Bone)dan Makassar. Untuk mengantisipasi perkembangan perusahaanyang semaki pesat, maka pada tanggal 18 Desember 1975, dilakukan perusahaan perihal tujuan perusahaan (pasal 2) dan disusun pemegang saham (pasal 20) dalam anggaran dasar perusahaan sehingga memungkinkan kegiatan-kegiatan perusahaan menjadi luas.

Dengan laju perkembangan yang pesat, maka pada tahun 1973. Hadji Kalla membuka kantor utama yang terletak di Jln. HOS Cokroaminoto No. 27 Makassar. Produk utama yang di perdagangkan oleh PT. Hadji Kalla saat ini adalah mobil merek Toyota yang merupakan penyalur tunggal untuk daerah pemasaran Sulawesi 
yang merupakan salah satu dealer dari PT. Toyota Astra Motor yang berkedudukan di Jakarta.

Visi Dan Misi

Visi : Menjadi dealer utama Toyota terbaik di Indonesia

Misi : Memuaskan kebutuhan transportasi untuk kualitas hidup dan bisnis yang lebih baik.

\section{Analisis Rasio Piutang}

Menilai piutang Berdasarkan Perputaran Piutang
a) Rata-rata Piutang (2010)
$=\frac{\text { piutang (awal tahun }+ \text { akhir tahun) }}{2}$
$=\frac{R p \cdot 4.089 .418 .800+R p \cdot 7 \cdot 183.608 .129}{2}$
$=R p .5 .636 .513 .465$
Rata-rata Piutang (2011)
$=\frac{\text { piutang (awal tahun }+ \text { akhir tahun) }}{2}$
$=\frac{R p \cdot 7 \cdot 183.608 .129+6.548 .966 .823}{2}$
$=R p \cdot 6.866 .287 .478$

Tabel 1

PT. HADJI KALLA

Rata-rata Piutang

\begin{tabular}{|c|c|c|}
\hline Keterangan & $\mathbf{2 0 1 0}$ & $\mathbf{2 0 1 1}$ \\
\hline Piutang awal & 4.089 .418 .800 & 7.183 .608 .129 \\
Piutang akhir & 7.183 .608 .129 & 6.866 .287 .479 \\
\hline Total & $\mathbf{5 . 6 3 6 . 5 1 3 . 4 6 5}$ & $\mathbf{8 . 1 6 6 . 2 8 7 . 4 7 6}$ \\
\hline
\end{tabular}

b) Perputaran Piutang (2010)

$$
\begin{aligned}
& =\frac{\text { Total Penjualan Kredit }}{\text { Rata-rata Piutang }} \\
& =\frac{R p .9 .112 .800 .000}{R p .5 .636 .513 .465} \\
& =1,62 \text { kali } \\
& =\frac{\text { Total Penjualan Kredit }}{\text { Rata-rata Piutang }} \\
& =\frac{\text { Rp.12.077.700.000 }}{R p .6 .866 .287 .476} \\
& =1,76 \mathrm{kali}
\end{aligned}
$$

Table 2

PT. HADJI KALLA

Perputaran Piutang

\begin{tabular}{|c|c|c|}
\hline Keterangan & $\mathbf{2 0 1 0}$ & $\mathbf{2 0 1 1}$ \\
\hline Total Penjualan Kredit & 9.112 .800 .000 & 12.077 .700 .000 \\
Rata-rata Piutang & 5.636 .513 .462 & 6.866 .287 .476 \\
\hline Ratio & $\mathbf{1 , 6 2}$ kali & $\mathbf{1 , 7 6}$ kali \\
\hline
\end{tabular}


Dari hasil perhitungan diperolah nilai rasio sebesar 1,62 untuk tahun 2010 dan 1,76 untuk tahun 2011. Rasio ini bisa diartikan bahwa jumlah piutang yang dimilikipada tahun 2010, dalam satu tahun perusahaan mampu menkonversi piutang menjadi kas sebanyak 1,62 kali, sedangkan pada tahun 2011 sebanyak 1,76 kali. Semakin tinggi ratio ini maka akan semakin baik kemampuan perusahaan dalam penagihan piutang yang dimiliki.

Menilai Piutang Berdasarkan Penerimaan piutang

$$
\begin{aligned}
\text { Rata-rata Penerimaan Piutang (2010) } & =\frac{365 \text { hari }}{\text { Perputaran Piutang }} \\
& =\frac{365}{1,62} \\
& =225 \text { hari } \\
\text { Rata-rata Penerimaan Piutang (2011) } & =\frac{365 \text { hari }}{\text { Perputaran Piutang }} \\
& =\frac{365}{1,76} \\
& =207 \text { hari }
\end{aligned}
$$

Table 3

PT. HADJI KALLA

Rata-rata Penerimaan Piutang

\begin{tabular}{|l|c|c|}
\hline \multicolumn{1}{|c|}{ Keterangan } & $\mathbf{2 0 1 0}$ & $\mathbf{2 0 1 1}$ \\
\hline 365 hari & 365 & 365 \\
Perputaran Piutang & 1,62 & 1,76 \\
\hline Ratio & $\mathbf{2 2 5}$ hari & $\mathbf{2 0 7}$ hari \\
\hline
\end{tabular}

Dengan melihat rasio rata-rata penerimaan piutang, kita bisa melihat dalam jangka waktu beberapa hari piutang akan diubah menjadi kas atau ditagih. Dari hasil perhitungan rata-rata penerimaan piutang untuk tahun 2010 adalah 225 hari, sedangkan untuk tahun 2011 adalah 207 hari. Semakin cepat rata-rata penerimaan piutang maka akan semakin baik kinerja PT. Hadji Kalla Cabang Palopo dalam mengelolah piutang.

Internal audit pada PT. Hadji Kalla Cabang Palopo berperan terhadap perencanaan dan pengendalian piutang dagang. Penyusunan mengemukakan hal ini berdasarkan hasil penelitian, dimana internal auditor pada PT. Hadji Kalla Cabang Palopo telah melaksanakan audit piutang dagang dengan efektif sehingga piutang dagang yang menjadi hak perusahaan dapat diterima dalam jumlah dan waktu yang tepat. Dengan adanya internal audit yang efektif maka akan berperan terhadap perencanaan dan pengendalian piutang.

Dengan kata lain, internal audit yang efektif akan meningkatkan pengendalian yang efektif pula. 


\section{Penutup}

Kesimpulan penelitian ini adalah: (a) Dari hasil perhitungan diperoleh nilai rasio sebesar 1,62 untuk tahun 2010 dan 1,76 untu tahun 2011, rasio ini diartikan bahwa jumlah piutang yang dimiliki pada tahun 2010 dalam satu tahun perusahaan mampu menkonversi piutang menjadi kas sebanyak 1,62 kali, sedangkan pada tahun 2011 sebanyak 1,76 kali, (b) Sedangkan dari hasil perhitungan rata-rata penerimaan piutang untuk tahun 2010 adalah 225 hari, sedangkan untuk tahun 2011 adalah 207 hari. Hal ini menunjukkan bahwa peranan internal audit terhadap perencanaan dan pengendalian piutang pada PT. Hadji Kalla Cabang palopo telah dilaksanakan dengan efektif. Adapun saran dari penelitian ini adalah internal audit dalam melaksanakan program pemeriksaan sebaiknya sesuai dengan waktu pelaksanaan yang tercantum dalam program pemeriksaan agar hasil pemeriksaan dapat diketahui dan dapat diambil keputusan dengan tepat dan benar.

\section{Daftar Pustaka}

A.A Anwar Prabu Mangkunegara. 2001 manajemen Sumber Daya Manusia Perusahaan, Bandung: Remaja Rosdakarya

Agoes, Sukrisno . 2004. Bunga Rampai Auditing, jakarta: Salemba Empat

Mulyadi, Auditing Buku I, Salemba Empat, Jakarta, 2002

S. Hadibroto. 2002 Akuntansi Intermediate. Jakarta: PT. Ichtiar Baru Van Hoeve.

S. Munawir , 2004, Analisis laporan Keuangan, Edisi Ke- Empat, Liberty, Yogyakarta

Skousen, Stice, 2004. Intermediate Accounting, Buku Satu, Edisi kelima belas, penerbit : Salemba Empat, Jakarta 